\title{
UROKINASE-TYPE PLASMINOGEN ACTIVATOR DOES NOT AFFECT IN VITRO BOVINE EMBRYO DEVELOPMENT AND QUALITY
}

\author{
Fotini Krania ${ }^{1}$, Eleni Dovolou ${ }^{1}$, Constantinos A. ReKKas ${ }^{2}$, Sonia Heras $^{3}$, \\ Ioannis PAPPAS ${ }^{4}$, Ann Van SOOM $^{3}$ and Georgios S. AMIRIDIS ${ }^{1 *}$ \\ ${ }^{1}$ Clinic of Obstetrics and Reproduction and ${ }^{4}$ Department of Pharmacology, \\ Veterinary Faculty, University of Thessaly, 224 Trikalon Street, 43100 Karditsa, Greece; \\ ${ }^{2}$ Veterinary Research Institute, HAO - 'DEMETER' (former NAGREF), Thermi, \\ Thessaloniki, Greece; ${ }^{3}$ Department of Reproduction, Obstetrics, and Herd Health, \\ Faculty of Veterinary Medicine, Ghent University, Merelbeke, Belgium
}

(Received 4 December 2014; accepted 17 February 2015)

The effects of modification of the in vitro embryo culture media (IVC) with the addition of urokinase-type plasminogen activator (u-PA) on the yield and/or quality of bovine embryos were examined in two experiments. In Experiment 1 , denuded embryos were cultured in semi-defined synthetic oviductal fluid (SOF) for seven days, while in Experiment 2 embryos were co-cultured with cumulus cell monolayer in a serum-containing SOF medium. Plasminogen activator activity (PAA) and plasminogen activator inhibition (PAI) were determined in all spent IVC media. At the activity used $(5 \mathrm{IU} / \mathrm{ml})$, u-PA had no effect either on in vitro embryo production rates or on embryo quality as revealed by gene expression analysis of 10 important mRNA transcripts related to apoptosis, oxidation, implantation and metabolism. PAA and PAI analysis indicated the need for wellbalanced plasminogen activators and inhibitors as a culture environment for embryo development. However, more research is needed to unveil the mechanism by which u-PA is involved in in vitro embryo production systems.

Key words: In vitro embryo production, in vitro embryo culture media, cleavage, u-PA receptor, bovine

Plasminogen activators (PAs) have been implicated in several physiological reproductive processes, including ovulation (Liu, 2004), fertilisation (Liu, 2007), embryo development (Whiteside et al., 2001), hatching (Kaaekuahiwi and Menino, 1990) and implantation (Strickland et al., 1976). There are at least two well-described types of PAs, the tissue-type plasminogen activator (t-PA) and the urokinase-type plasminogen activator (u-PA), which convert the abundant proenzyme plasminogen to plasmin (Saksela, 1985). Unrestrained activity of the plasminogen activators / plasmin system (PAs / PL system) is prevented by spe-

*Corresponding author; E-mail: gsamir@vet.uth.gr; Phone: 0030 (244) 106-6073 
cific inhibitors, binding to either PAs (plasminogen activator inhibitors, PAIs) or plasmin (plasmin inhibitors, PIs) (Saksela, 1985).

Urokinase-PA is synthesised and released as a single-chain proenzyme (pro-u-PA) with little or no activity (Blasi et al., 1987). Activation of pro-u-PA is facilitated through binding to a specific cell-membrane receptor (u-PAR), thus localising the plasminogen activation near the cell surface (Vassalli et al., 1985). PAs and u-PAR mRNA expression, as well as PAs activity, were found to be upregulated in a spatiotemporal manner after a GnRH-induced gonadotropin surge in the bovine periovulatory follicle, indicating their significant contribution to ovulation (Dow et al., 2002). In the same study, u-PAR mRNA was found to be primarily localised in the granulosa and theca cells, $6 \mathrm{~h}$ after the gonadotropin surge, while in vitro maturation of denuded bovine oocytes did not result in any increase in u-PA activity, suggesting that increased u-PA might not be of oocyte origin, but is physiologically provided by cumulus cells (Park et al., 1999).

u-PA mRNA was found to be highly expressed in bovine zygotes, it was reduced at 2- to 4-cell stage embryos, followed by an upregulation in morula and blastocyst stage. Plasminogen activator activity (PAA) was detected in all in vitro embryo culture media, with $60 \%$ of it being attributed to u-PA activity (Whiteside et al., 2001). Messenger RNA expression and/or activity of u-PA have been also detected in human blastocysts produced in vitro (Khamsi et al., 1996). Addition of u-PA in the in vitro culture (IVC) medium of bovine cumulus cellenclosed embryos, at concentrations adjusting PAA close to that of the in vivo environment, increased embryo development to early morula stage (Papanikolaou et al., 2008). u-PA is also present in late stage cultured in vivo produced bovine embryos; it is mostly produced by intact embryos and trophoblastic vesicles rather than embryonic discs (Berg and Menino, 1992).

In the rat, transcriptional activity of u-PA was first detected in the 2-cell stage embryos and onward to the blastocyst stage, whereas mRNA expression of t-PA was found only in oocytes and 2-cell stage embryos (Zhang et al., 1994). In the same study, PAA was detected in the culture media of oocytes and embryos and most of it was attributed to u-PA, clearly demonstrating that u-PA activity is determinant for early embryo development and implantation.

We hypothesised that u-PA addition in culture media would favour embryo development. In this context, we investigated the effect of exogenous u-PA on denuded embryos, cultured in serum-free semi-defined media, and on embryos co-cultured with cumulus cells in serum-containing media. 


\section{Materials and methods}

\section{Experimental design}

In the first experiment (Exp. 1), 1631 putative zygotes were used. In the second experiment (Exp. 2), 629 putative zygotes were used for IVC modification.

In vitro embryo production (IVP)

All chemicals were purchased from Sigma-Aldrich (Taufkirchen, Munich, Germany), unless otherwise noted.

For both experiments bovine ovaries were collected from local abattoirs and $2-8 \mathrm{~mm}$ follicles were aspirated for the collection of cumulus-oocyte complexes (COCs).

For gene expression analysis, day 7 blastocysts (pools of 5, four replicates) of each group were snap frozen into liquid nitrogen and were stored at $-80^{\circ} \mathrm{C}$.

\section{Experiment 1: Effect of u-PA addition in IVC, on denuded embryos cultured under semi-defined conditions}

Bovine embryos were produced as previously described with slight modifications (Wydooghe et al., 2014). For in vitro maturation (IVM), groups of 5055 COCs were placed in $500 \mu \mathrm{l}$ of TCM-199 supplemented with $20 \mathrm{ng} / \mathrm{ml}$ epidermal growth factor (EGF) and $50 \mathrm{mg} / \mathrm{ml}$ gentamicin. Then, COCs were incubated for $24 \mathrm{~h}$ in humidified air with $5 \% \mathrm{CO}_{2}$ at $39^{\circ} \mathrm{C}$. Frozen semen was thawed and separated through a discontinuous Percoll density gradient [45 and 90\% (v/v), GE Healthcare Biosciences, Uppsala, Sweden], followed by a washing step. For in vitro fertilisation (IVF), the final sperm concentration of $1 \times 10^{6}$ spermatozoa/ml was adjusted in $500 \mu \mathrm{l}$ of IVF-TALP [bicarbonate-buffered Tyrode's solution, supplemented with bovine serum albumin (BSA, $6 \mathrm{mg} / \mathrm{ml}$; A8806) and heparin $20 \mathrm{mg} / \mathrm{ml}$ ] medium already containing the oocytes. Gametes were co-incubated for at least $22 \mathrm{~h}$ at $39{ }^{\circ} \mathrm{C}$ under $5 \% \mathrm{CO}_{2}$ in air and maximum humidity. All presumptive embryos $(n=1631$ in 8 replicates $)$ were vortexed to remove cumulus cells, transferred in groups of 25 to $400 \mu \mathrm{l}$ of synthetic oviductal fluid (SOF) containing $5 \mu \mathrm{g} / \mathrm{ml}$ insulin, $5 \mu \mathrm{g} / \mathrm{ml}$ transferrin, $5 \mathrm{ng} / \mathrm{ml}$ selenium and $0.4 \%$ BSA. At this stage, IVC medium was modified with the addition of $\mathrm{u}-$ PA from human urine (U0633, EC 3.4.21.73) at a final activity of $5 \mathrm{IU} / \mathrm{ml}$. Embryo cultures were covered with mineral oil and incubated at $39{ }^{\circ} \mathrm{C}$, under an atmosphere of $5 \% \mathrm{CO}_{2}, 5 \% \mathrm{O}_{2}$ and $90 \% \mathrm{~N}_{2}$, for seven days. Cleavage rates were estimated $45 \mathrm{~h}$ post insemination (pi) and blastocyst formation rates on day 7. 
Experiment 2: Effect of u-PA addition in IVC, on embryos cultured on a cumulus cell monolayer under serum-containing conditions

Bovine embryos were produced as previously described (Dovolou et al., 2014; Krania et al., 2015).

COCs were matured as in Exp. 1 in TCM-199, supplemented with $10 \mathrm{ng} / \mathrm{ml}$ EGF and $10 \% \mathrm{v} / \mathrm{v}$ of fetal calf serum (FCS), and were fertilised with swim-up separated sperm $\left(1 \times 10^{6}\right.$ spermatozoa $/ \mathrm{ml}$ in Tyrode's medium $)$ as previously described in detail (Dovolou et al., 2014). The day of fertilisation was considered as day $0(\mathrm{~d} 0)$, which was also the day of cumulus cells monolayer preparation. Only putative zygotes $(n=629$ in 6 replicates), were selected for the IVC. Groups of 25 denuded embryos were transferred to the cumulus cells monolayer IVC media $(400 \mu \mathrm{l})$ and covered with mineral oil. The culture medium consisted of SOF enriched with $5 \% \mathrm{FCS}$ and $6 \mathrm{mg} / \mathrm{ml} \mathrm{BSA}$, modified or not with u-PA, at a final activity of $5 \mathrm{IU} / \mathrm{ml}$, and embryos were cultured under the same conditions as in Exp 1.

\section{Preparation of cumulus cells monolayer (CC monolayer)}

The cumulus cells $(\mathrm{CC})$ monolayer was prepared using 55 in vitro matured COCs, as previously described (Goovaerts et al., 2009). Cumulus cells were mechanically removed by multiple pipetting, using a stripping pipette (Cook Medical, Bloomington, IN, USA). The CC suspension was centrifuged for $10 \mathrm{~min}$ at $67 \times g$ and the pellet was resuspended in SOF containing 5\% FCS at a concentration of $25 \times 10^{3}$ viable $\mathrm{CC} / \mathrm{ml}$. Then, $500 \mu \mathrm{l}$ of the SOF-CC suspension was transferred to a 4-well culture dish (Nunc ${ }^{\circledR}$-Thermofisher Scientific, Roskilde, Denmark). Cells were incubated at $39{ }^{\circ} \mathrm{C}$ under $5 \% \mathrm{CO}_{2}$, in air and maximum humidity, for $24 \mathrm{~h}$ (until day 1). A CC monolayer was formed onto the bottom of the dish; SOF medium was discarded and replaced by $400 \mu \mathrm{l}$ of fresh preequilibrated SOF.

\section{$R N A$ extraction and reverse transcription $(R T)$}

A Pico Pure RNA isolation kit $^{\circledR}$ (Arcturus, Mountain View, CA, USA) was used for total RNA extraction. DNase treatment (Invitrogen, Gaithesburg, MD, USA) was performed in all RNA purification columns to ensure that no genomic DNA (gDNA) contamination would interfere with the results.

First strand cDNA was immediately synthesised from the total amount of RNA using the High-Capacity cDNA reverse transcription kit ${ }^{\circledR}$ (Applied Biosystems, Foster City, CA, USA). Each RT reaction consisted of $15 \mu \mathrm{l}$ of DNasetreated RNA and an equal volume of RT master mix (RT random primers, dNTPs Mix, RT buffer, RNase inhibitor and MultiScribe reverse transcriptase). Thermal cycling conditions for RT were $25^{\circ} \mathrm{C}$ for $10 \mathrm{~min}, 37^{\circ} \mathrm{C}$ for $2 \mathrm{~h}$ followed by a denaturation step at $85^{\circ} \mathrm{C}$ for $5 \mathrm{~min}$ and flash cooling at $4{ }^{\circ} \mathrm{C}$. 
Real-Time Polymerase Chain Reaction (RT-PCR)

Genes related to apoptosis (survivin, $B B C 3$ and $B C L 2 L 1$ ), fructose transport and metabolism (GLUT-5), implantation (PLAC8), oxidative stress (MnSOD), carbohydrate metabolism $(A K R 1 B 1)$, regulation of cell proliferation $(C O X-2)$ and proteolysis ( $P L G$ and $P L A U R)$ were studied.

Primers used for RT-PCR to amplify the candidate genes were designed with PRIMER 3 software and purchased from Vbc biotech (Vienna, Austria). The primer sequences are listed in Table 1.

Table 1

Primers used for RT-PCR

\begin{tabular}{|c|c|c|c|}
\hline Genes & GenBank Accession no. & Primer sequence $5^{\prime} \rightarrow 3^{\prime}$ & $\begin{array}{c}\text { Amplicon } \\
\text { size (bp) }\end{array}$ \\
\hline GAPDH & NM_001034034 & $\begin{array}{l}\text { (F) 5'-CAAGTTCAACGGCACAGTCAAGG-3' } \\
\text { (R) 5'-ACATACTCAGCACCAGCATCACC-3' }\end{array}$ & 123 \\
\hline SDHA & NM_174178.2 & $\begin{array}{l}\text { (F) 5'-GCAGAACCTGATGCTTTGTG-3' } \\
\text { (R) 5'-CGTAGGAGAGCGTGTGCTT-3' }\end{array}$ & 185 \\
\hline YWHAZ & NM_174814.2 & $\begin{array}{l}\text { (F) 5'-GCATCCCACAGACTATTTCC-3' } \\
\text { (R) 5'-GCAAAGACAATGACAGACCA-3' }\end{array}$ & 120 \\
\hline PLAC8 & NM_001076987 & $\begin{array}{l}\text { (F) 5'-AATGAATGCTGTCTGTGCGGAAC-3' } \\
\text { (R) 5'-AGTGCGATTGGCTCTCCTTCTG-3' }\end{array}$ & 167 \\
\hline AKR1B1 & NM_001012519 & $\begin{array}{l}\text { (F) 5'-AGGAGAAAGTGGTGAAGCGTGAG-3', } \\
\text { (R) 5'-ATGAGGTAGAGGTCCAGGTAGTCC-3' }\end{array}$ & 138 \\
\hline survivin & NM_001001855 & $\begin{array}{l}\text { (F) 5'-GCCGTCAACCGCTGGATTTG-3' } \\
\text { (R) 5'-CGTTCTCAGTGGGACAGTGGATG-3' }\end{array}$ & 198 \\
\hline BBC3 & XM_002695182.2 & $\begin{array}{l}\text { (F) 5'-CATGAAGAGCAAATGAGCCAAACG-3' } \\
\text { (R) 5'-GCAGAGCACAGGATTCACAGTC-3' }\end{array}$ & 193 \\
\hline $\mathrm{COX}-2$ & NM_174445 & $\begin{array}{l}\text { (F) 5'-TCTGGTGCCTGGTCTGATGATG-3' } \\
\text { (R) 5'-GGATTAGCCTGCTTGTCTGGAAC-3' }\end{array}$ & 127 \\
\hline BCL2L1 & NM_001077486 & $\begin{array}{l}\text { (F) 5'-TGACTGTGGCTGGTGTGGTTC-3' } \\
\text { (R) 5'-CAATGGTGGCTGGACGGAGAG-3' }\end{array}$ & 123 \\
\hline GLUT-5 & NM_001101042 & $\begin{array}{l}\text { (F) 5'-ATAGCTGCCTTTGGGTCGTC-3' } \\
\text { (R) 5'-CAGCAAGGTTCCTTTTCTGCC-3' }\end{array}$ & 243 \\
\hline MnSOD & NM_201527 & $\begin{array}{l}\text { (F) 5'-GCACCACAGCAAGCACCAC-3' } \\
\text { (R) 5'-GGGCTCAGATTTGTCCAGAAGATG-3' }\end{array}$ & 156 \\
\hline PLG & NM_173951 & $\begin{array}{l}\text { (F) 5'-GGCGGTGGTGTTCCTACTTCTC-3' } \\
\text { (R) 5'-GTCTGTCTCCTCCTCACACTTGG-3' }\end{array}$ & 163 \\
\hline PLAUR & NM_174423.3 & $\begin{array}{l}\text { (F) 5'-GTCCTGAGTGTGTGGGAAGG-3' } \\
\text { (R) 5'-CAGTAGCATCTCGACCAGGG-3' }\end{array}$ & 177 \\
\hline
\end{tabular}


RT-PCR was performed in LightCycler ${ }^{\circledR} 2.0$ Carousel-Based System (Roche-Applied Science, Manheim, Germany) using the Kapa SYBR ${ }^{\circledR}$ Fast qPCR kit (Kapa Biosystems, Woburn, MA, USA). All RT-PCR reactions mixtures prepared in a final volume of $20 \mu \mathrm{l}$ containing $1 \mu \mathrm{l}$ embryo's cDNA of the same concentration, $200 \mathrm{nM}$ of each specific primer, 1x KAPA SYBR FAST qPCR Master Mix-Universal and $250 \mathrm{ng} / \mu \mathrm{l}$ BSA (New England Biolabs B900S, Ipswich, MA, USA) for prevention of DNA polymerase and template binding to the glass capillaries used for this PCR system. RT-PCR cycling conditions for amplification were 1 cycle for $10 \mathrm{~min}$ at $95^{\circ} \mathrm{C}$, followed by 55 cycles of $10 \mathrm{sec}$ at $95^{\circ} \mathrm{C}$, of $10 \mathrm{sec}$ at $58^{\circ} \mathrm{C}$ and of $15 \mathrm{sec}$ at $72{ }^{\circ} \mathrm{C}$; each amplicons' specificity was verified by a melting curve analysis given by the LightCycler software. Three endogenous reference genes (GAPDH, YWHAZ and SDHA) were selected for data normalisation, using the geNorm ${ }^{\mathrm{TM}}$ programme (Vandesompele et al., 2002). Fold changes in the relative gene expression of each target gene were determined using the formula $2^{-\Delta \Delta \mathrm{Ct}}$.

\section{Plasminogen Activator Activity and Plasminogen Activator Inhibition (PAA and PAI)}

In both experiments, day 7 IVC spent media of all groups were centrifuged $(120 \times \mathrm{g}, 20 \mathrm{~min}$, at room temperature) and the supernatant was stored at $-20{ }^{\circ} \mathrm{C}$, for PAA and PAI analysis.

PAA was determined by a spectrophotometric method, using the chromogenic substrate S-2251 (Chromogenix, Milan, Italy), as previously described (Smokovitis et al., 1987).

PAI activity was determined by a previously described procedure (Rekkas et al., 2002).

\section{Statistical analysis}

Cleavage and blastocyst formation rates were analysed using the chisquare test. Independent samples test was used for the analysis of possible differences on both gene expression and PAA or PAI results. Moreover, linear regression analysis was also performed to trace possible relations between PAA, PAI and embryo developmental results.

Data were analysed using the statistical software package SPSS ${ }^{\circledR} 17.0$ for Windows. In all cases, the probability of $\mathrm{P}<0.05$ was considered significant.

\section{Results}

\section{Experiment 1}

Supplementation of semi-defined IVC medium with $5 \mathrm{IU} / \mathrm{ml} \mathrm{u}-\mathrm{PA}$ had no effect on cleavage rate, on day 7 blastocyst formation rates (Table 2) and on gene expression (Fig. 1). In the u-PA groups, the total PAA was significantly higher 
than in the controls $(\mathrm{P}<0.0001)$. Based on the PAI results against u-PA (u-PAI), no significant difference was found between the two groups studied. In contrast, the corresponding PAI levels against t-PA (t-PAI) were significantly higher in the u-PA treated group. Both PAA and PAI results are shown in Table 3.

Table 2

Effects of u-PA addition in IVC on embryo development (mean \pm SEM)

\begin{tabular}{lccccc}
\hline & Group & $\begin{array}{c}\text { Putative } \\
\text { zygotes } \\
(\mathrm{N})\end{array}$ & $\begin{array}{c}\text { Cleavage } \\
(\%)\end{array}$ & $\begin{array}{c}\text { Day 7 blastocysts/ } \\
\text { putative zygotes } \\
(\%)\end{array}$ & $\begin{array}{c}\text { Day } 7 \text { blastocysts/ } \\
\text { cleaved zygotes } \\
(\%)\end{array}$ \\
\hline Experiment 1 & Control & 775 & $80.1 \pm 3.4$ & $23.5 \pm 1.8$ & $29.2 \pm 1.6$ \\
& u-PA & 856 & $78.7 \pm 2.8$ & $25.1 \pm 2.7$ & $32.0 \pm 2.9$ \\
\hline Experiment 2 & Control & 310 & $74.2 \pm 2.7$ & $25.1 \pm 2.9$ & $33.9 \pm 3.7$ \\
& u-PA & 319 & $76.2 \pm 4.0$ & $22.8 \pm 3.1$ & $30.0 \pm 3.9$ \\
\hline
\end{tabular}

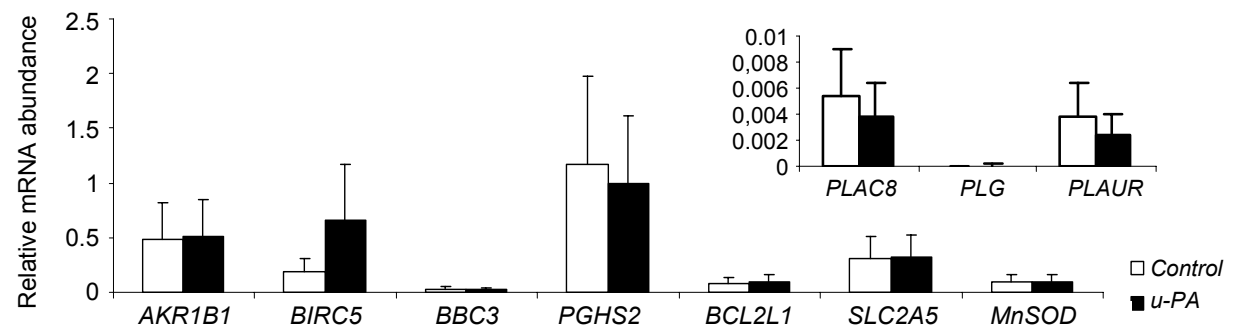

Fig. 1. Effect of u-PA addition in IVC on the quality of day 7 blastocysts (Experiment 1). Gene expression results are depicted in two different scale graphs and are presented as mean \pm SD of the four replicates

Table 3

Plasminogen Activator Activity (PAA) and Plasminogen Activator Inhibition (PAI) in day 7 (D7) IVC spent medium (mean \pm SEM)

\begin{tabular}{lcccc}
\hline & Group & $\begin{array}{c}\text { PAA } \\
(\mathrm{u}-\mathrm{PA} \text { IU/0.1 ml) }\end{array}$ & $\begin{array}{c}\text { PAI } \\
(\mathrm{t}-\mathrm{PA} \text { IU/0.1 ml })\end{array}$ & $\begin{array}{c}\text { PAI } \\
(\mathrm{u}-\mathrm{PA} \text { IU/0.1 ml })\end{array}$ \\
\hline Experiment 1 & Control & $1.5 \pm 0.1^{\mathrm{a}}$ & $22.3 \pm 1.7^{\mathrm{a}}$ & $0.24 \pm 0.02$ \\
& $\mathrm{u}-\mathrm{PA}$ (D7) & $7.1 \pm 0.5^{\mathrm{b}}$ & $30.1 \pm 1.5^{\mathrm{b}}$ & $0.28 \pm 0.04$ \\
& $\mathrm{u}-\mathrm{PA}$ (D0) & $8.2 \pm 0.3^{\mathrm{b}}$ & $32.2 \pm 0.9^{\mathrm{b}}$ & $0.36 \pm 0.04$ \\
\hline Experiment 2 & Control & $0.9 \pm 0.1$ & $16.6 \pm 0.7$ & $0.17 \pm 0.02$ \\
& u-PA (D7) & $0.8 \pm 0.1^{\mathrm{a}}$ & $15.2 \pm 0.7$ & $0.15 \pm 0.01$ \\
& u-PA (D0) & $1.4 \pm 0.1^{\mathrm{b}}$ & $17.4 \pm 0.9$ & $0.16 \pm 0.01$
\end{tabular}

${ }^{a}{ }^{a}$ Different superscripts in the same column denote significant differences between groups in each experiment $(\mathrm{P}<0.0001)$. Day $0(\mathrm{D} 0) \mathrm{u}-\mathrm{PA}$-treated culture media used as an internal control to test the effectiveness of modification of the IVC medium 


\section{Experiment 2}

No differences were found in cleavage rate, in day 7 blastocyst formation rates (Table 2) and in gene expression (Fig. 2) between the control and the u-PA treated group. PAA and PAI levels did not differ between the two groups studied $(\mathrm{P}>0.05)$. On day 0 PAA was higher in experiment 1 than in experiment 2 . The results referring to PAA and PAI are presented in Table 3.

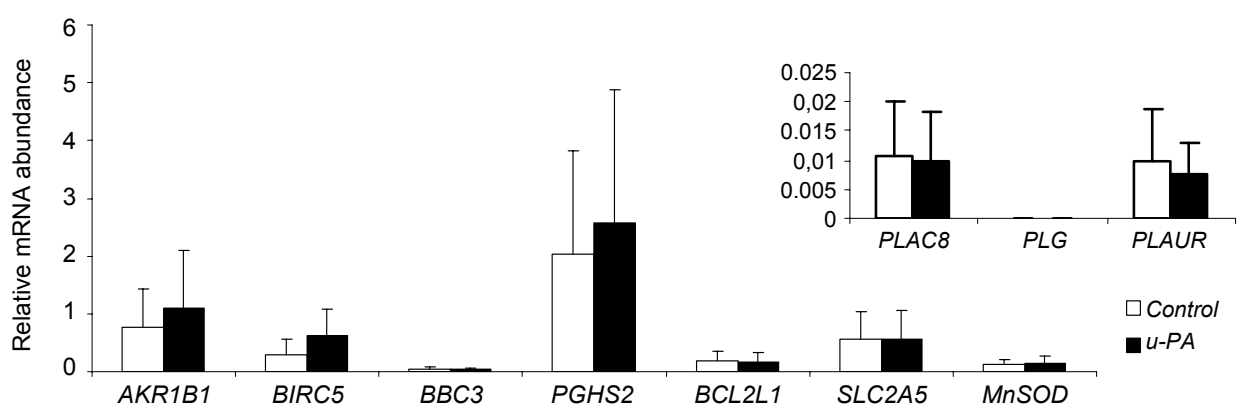

Fig. 2. Effect of u-PA addition on relative mRNA abundance (mean $\pm \mathrm{SD}$ ) of the ten genes studied. Embryos cultured with a cumulus cell monolayer in SOF medium with FCS (Experiment 2)

\section{Discussion}

The results of the present study indicate that our initial hypothesis has not been confirmed, since neither the yield nor the quality of blastocysts was affected by the addition of u-PA.

In a previous study it was reported that the addition of u-PA to the IVC medium significantly increased the 4-cell stage bovine embryo rates, when cultured for $48 \mathrm{~h}$ enclosed by their cumulus cells (Papanikolaou et al., 2008). Cumulus cells in an oviduct epithelial cell-conditioned culture medium have been considered beneficial during early cleavage stages of in vitro-derived bovine zygotes (Thomas and Seidel, 1993), albeit those cells are metabolically active and therefore, it is necessary to unravel all possible, but complex, cell-to-embryos interactions. Nowadays, the use of somatic cells in bovine IVP has been abandoned; here, cumulus cells were solely added to facilitate the study of possible effects of u-PA on embryo development. It has been proposed that u-PA activity is physiologically provided by cumulus cells instead of oocytes (Park et al., 1999). It is therefore possible that cumulus cells might moderate u-PA activity. In this study, co-culture of embryos surrounded by their cumulus cells led to poor IVP results (approximately 10-12\% day 7 blastocyst rates, data not shown) when cultured until the blastocyst stage (both in control and u-PA treated groups). Hence, we used the cumulus cell monolayer as an alternative protocol to provide embryos with those cells that are possibly carrying the u-PAR, thereby producing plasmin activity. 
In Exp. 1, a significant increase in PAs activity and PAI against t-PA (t$\mathrm{PAI}$ ) in the u-PA-treated group compared to the control was observed. PAA levels were in positive correlation with t-PAI levels $(\mathrm{P}<0.0001)$. In contrast, no changes were recorded in the inhibitory activity against u-PA (u-PAI) between the two groups studied. Even though we are not able to discriminate between uPA or t-PA activity contribution to the total PAA, through the experiments carried out in this study, PAA results are in accordance with the inclusion of exogenous u-PA in semi-defined media in the absence of any cell. In bovine blastocysts, $60 \%$ of the total PAA produced in the spent media was attributed to u-PA activity (Whiteside et al., 2001). Another interesting finding is that u-PA treatment caused an increase in the t-PAI levels but not in the u-PAI, indicating that excessive u-PA or plasmin activity might be physiologically restrained by a specific type of PAI release. Among the described PAIs, PAI-2 is regarded as a relatively poor inhibitor of t-PA and is associated with the two-chain u-PA more than 400 times higher than with the two-chain t-PA (Thorsen et al., 1988). Consequently, in our case, this significant increase in PAI levels against t-PA is probably indicative of a subsequent increase of the PAI-1. Supplements contained in our semi-defined medium used for embryo culture, such as selenium and insulin, have been reported to alter u-PA and PAI-1 expression, respectively (Alessi et al., 1988; Yoon et al., 2001).

In Exp. 2, no significant differences were recorded either in PAA or PAI results between untreated and u-PA treated spent media. However, in u-PAtreated spent media, PAA was positively related to t-PA inhibitory activity (tPAI; linear regression, $\mathrm{P}<0.05)$. Secreted inhibitors are essential to neutralise excessive PAA produced in the medium, and cumulus cells might play a role in this process to support embryonic development. Secretion rate of PAs and/or PAIs can be altered by several hormones or hormone-like substances such as gonadotropins, sex steroids, prostaglandins $\mathrm{E}_{1}$ or $\mathrm{E}_{2}$, several growth factors and substances raising the cAMP (Saksela, 1985; Blasi et al., 1987); all these substances might have been provided to the embryo culture by FCS addition, which might explain the differences in PAA between the two treatment groups at the starting point (day 0). We hypothesised that the presence of cumulus cells and FCS in the culture media might alter the PAA in the spent media by releasing PAs and/or PAIs, thus affecting the PAA observed in the spent media. These results may explain why PAA and PAI levels in the spent media of u-PA-treated embryos did not show any divergence from the control groups.

Control and u-PA-treated embryos were analysed for relative mRNA expression of transcripts involved in various biological processes. The set of selected genes included genes related to apoptosis [survivin (Park et al., 2007), $B C L 2 L 1$ (Cory et al., 2003) and BBC3 (Hikisz and Kiliańska, 2012)], to antioxidant protection and embryo quality $[M n S O D$ (Lonergan et al., 2003)], to implantation [COX-2, PLAC8 and AKR1B1 (El-Sayed et al., 2006)], and metabolism 
(GLUT-5). As no difference was detected in either experiment, we infer that either u-PA does not affect the aforementioned functions, or its action is exerted through different pathways that have not been analysed in this study. Lastly, $P L G$ and PLAUR mRNA expression were selected to investigate whether u-PA addition altered the relative mRNA abundance of those related genes which are members of the PAs/PL system. PLG mRNA expression was not detected either in control or in u-PA treated embryos, which is in accordance with our previous results for PLG expression in control day 7 embryos (Krania et al., 2015).

Despite its significant role in early and late embryo development, the inclusion of exogenous u-PA in the in vitro bovine embryo culture medium, at a final activity of $5 \mathrm{IU} / \mathrm{ml}$, did not have any effect on embryo yield and/or quality under the experimental culture conditions used in this study. Gene expression analysis of the produced u-PA-treated blastocysts confirmed the phenotypic invariance that arose from IVP results. Investigation of the altered culture environment related to PAs and PAIs activity revealed the importance of a culture system to maintain a balanced activity between activators and inhibitors in a highly regulated manner.

\section{Acknowledgements}

Fotini Krania was financially supported with a PhD scholarship ('Heraclitus II') through the Operational Programme 'Education and Lifelong Learning' (NSRF 20072012) funded by the EU and the Greek government. For all experiments performed at Ghent University, Fotini Krania was supported by a short-term mission provided by the COST Action FA0702-GEMINI - 'Maternal interactions with gametes \& embryos'.

\section{References}

Alessi, M. C., Juhan-Vague, I., Kooistra, T., Declerck, P. J. and Collen, D. (1988): Insulin stimulates the synthesis of plasminogen activator inhibitor 1 by the human hepatocellular cell line Hep G2. Thromb. Haemost. 60, 491-494.

Berg, D. A. and Menino, A. R. Jr. (1992): Bovine embryos produce a urokinase-type plasminogen activator. Mol. Reprod. Dev. 31, 14-19.

Blasi, F., Vassalli, J. D. and Danø, K. (1987): Urokinase-type plasminogen activator: proenzyme, receptor, and inhibitors. J. Cell Biol. 104, 801-804.

Cory, S., Huang, D. C. and Adams, J. M. (2003): The Bcl-2 family: roles in cell survival and oncogenesis. Oncogene 22, 8590-8607.

Dovolou, E., Messinis, I. E., Periquesta, E., Dafopoulos, K., Gutierrez-Adan, A. and Amiridis, G. S. (2014): Ghrelin accelerates in vitro maturation of bovine oocytes. Reprod. Domest. Anim. 49, 665-672.

Dow, M. P., Bakke, L. J., Cassar, C. A., Peters, M. W., Pursley, J. R. and Smith, G. W. (2002): Gonadotropin surge-induced up-regulation of the plasminogen activators (tissue plasminogen activator and urokinase plasminogen activator) and the urokinase plasminogen activator receptor within bovine periovulatory follicular and luteal tissue. Biol. Reprod. 66, $1413-1421$. 
El-Sayed, A., Hoelker, M., Rings, F., Salilew, D., Jennen, D., Tholen, E., Sirard, M. A., Schellander, K. and Tesfaye, D. (2006): Large-scale transcriptional analysis of bovine embryo biopsies in relation to pregnancy success after transfer to recipients. Physiol. Genomics 28, 84-96.

Goovaerts, I. G., Leroy, J. L., Van Soom, A., De Clercq, J. B., Andries, S. and Bols, P. E. (2009): Effect of cumulus cell coculture and oxygen tension on the in vitro developmental competence of bovine zygotes cultured singly. Theriogenology 71, 729-738.

Hikisz, P. and Kiliańska, Z. M. (2012): PUMA, a critical mediator of cell death-one decade on from its discovery. Cell Mol. Biol. Lett. 17, 646-669.

Kaaekuahiwi, M. A. and Menino, A. R. Jr. (1990): Relationship between plasminogen activator production and bovine embryo development in vitro. J. Anim. Sci. 68, 2009-2014.

Khamsi, F., Armstrong, D. T. and Zhang, X. (1996): Expression of urokinase-type plasminogen activator in human preimplantation embryos. Mol. Hum. Reprod. 2, 273-276.

Krania, F., Dovolou, E., Rekkas, C. A., Theodosiadou, E. K., Pappas, I. and Amiridis, G. S. (2015): Effects of addition of tissue-type Plasminogen Activator in in vitro fertilization medium on bovine embryo development and quality. Reprod. Domest. Anim. 50, 112-120.

Liu, Y. X. (2004): Plasminogen activator/plasminogen activator inhibitors in ovarian physiology. Front. Biosci. 9, 3356-3373.

Liu, Y. X. (2007): Involvement of plasminogen activator and plasminogen activator inhibitor type 1 in spermatogenesis, sperm capacitation, and fertilization. Semin. Thromb. Hemost. 33, 29-40.

Lonergan, P., Rizos, D., Gutierrez-Adán, A., Moreira, P. M., Pintado, B., de la Fuente, J. and Boland, M. P. (2003): Temporal divergence in the pattern of messenger RNA expression in bovine embryos cultured from the zygote to blastocyst stage in vitro or in vivo. Biol. Reprod. 69, 1424-1431.

Papanikolaou, T., Amiridis, G. S., Dimitriadis, I., Vainas, E. and Rekkas, C. A. (2008): Effect of plasmin, plasminogen activators and a plasmin inhibitor on bovine in vitro embryo production. Reprod. Fertil. Dev. 20, 320-327.

Park, K. W., Choi, S. H., Song, X. X., Funahashi, H. and Niwa, K. (1999): Production of plasminogen activators (PAs) in bovine cumulus-oocyte complexes during maturation in vitro: effects of epidermal growth factor on production of PAs in oocytes and cumulus cells. Biol. Reprod. 61, 298-304.

Park, S. Y., Kim, E. Y., Jeon, K., Cui, X. S., Lee, W. D., Kim, N. H., Park, S. P. and Lim, J. H. (2007): Survivin acts as anti-apoptotic factor during the development of bovine preimplantation embryos. Mol. Reprod. Dev. 74, 582-590.

Rekkas, C. A., Besenfelder, U., Havlicek, V., Vainas, E. and Brem, G. (2002): Plasminogen activator activity in cortical granules of bovine oocytes during in vitro maturation. Theriogenology 57, 1897-1905.

Saksela, O. (1985): Plasminogen activation and regulation of pericellular proteolysis. Biochim. Biophys. Acta 823, 35-65.

Smokovitis, A., Kokolis, N., Alexopoulos, C., Alexaki, E. and Eleftheriou, E. (1987): Plasminogen activator activity, plasminogen activator inhibition and plasmin inhibition in spermatozoa and seminal plasma of man and various animal species. Effect of plasmin on sperm motility. Fibrinolysis 1, 253-257.

Strickland, S., Reich, E. and Sherman, M. I. (1976): Plasminogen activator in early embryogenesis: enzyme production by trophoblast and parietal endoderm. Cell 9, 231-240.

Thomas, W. K. and Seidel, G. E. Jr. (1993): Effects of cumulus cells on culture of bovine embryos derived from oocytes matured and fertilized in vitro. J. Anim. Sci. 71, 2506-2510.

Thorsen, S., Philips, M., Selmer, J., Lecander, I. and Astedt, B. (1988): Kinetics of inhibition of tissue-type and urokinase-type plasminogen activator by plasminogen-activator inhibitor type 1 and type 2. Eur. J. Biochem. 175, 33-39. 
Vandesompele, J., De Preter, K., Pattyn, F., Poppe, B., Van Roy, N., De Paepe, A. and Speleman, F. (2002): Accurate normalization of real-time quantitative RT-PCR data by geometric averaging of multiple internal control genes. Genome Biol. 3 (7), RESEARCH0034. Epub 18 June 2002.

Vassalli, J. D., Baccino, D. and Belin, D. (1985): A cellular binding site for the Mr 55,000 form of the human plasminogen activator, urokinase. J. Cell Biol. 100, 86-92.

Whiteside, E. J., Kan, M., Jackson, M. M., Thompson, J. G., McNaughton, C., Herington, A. C. and Harvey, M. B. (2001): Urokinase-type plasminogen activator (UPA) and matrix metalloproteinase-9 (MMP-9) expression and activity during early embryo development in the cow. Anat. Embryol. 204, 477-483.

Wydooghe, E., Heras, S., Dewulf, J., Piepers, S., Van den Abbeel, E., De Sutter, P., Vandaele, L. and Van Soom, A. (2014): Replacing serum in culture medium with albumin and insulin, transferrin and selenium is the key to successful bovine embryo development in individual culture. Reprod. Fertil. Dev. 26, 717-724.

Yoon, S. O., Kim, M. M. and Chung, A. S. (2001): Inhibitory effect of selenite on invasion of HT1080 tumor cells. J. Biol. Chem. 276, 20085-20092.

Zhang, X., Kidder, G. M., Zhang, C., Khamsi, F. and Armstrong, D. T. (1994): Expression of plasminogen activator genes and enzymatic activities in rat preimplantation embryos. J. Reprod. Fertil. 101, 235-240. 